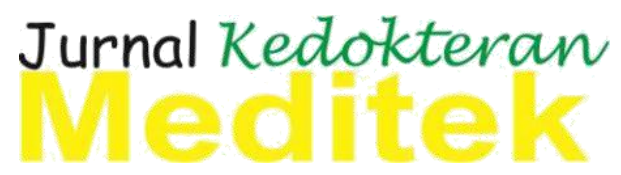

p-ISSN : 2686-1437

e-ISSN : 2686-0201

http://ejournal.ukrida.ac.id/ojs/index.php/Meditek/index

\title{
Pengaruh Indeks Massa Tubuh terhadap Klasifikasi Tekanan Darah pada Penduduk Usia Produktif di Kota Medan
}

\author{
Darren Gosal', Yohanes Firmansyah ${ }^{2}$, Ernawati $\mathrm{Su}^{2}$ \\ ${ }^{1}$ Fakultas Kedokteran dan Ilmu Kesehatan, Universitas Katolik Atma Jaya, Jakarta, Indonesia \\ ${ }^{2}$ Departemen Ilmu Kesehatan Masyarakat dan Kedokteran Keluarga, Universitas Katolik Atma Jaya, Jakarta, \\ Indonesia \\ Alamat Korespondensi: darren_gosal@ hotmail.com
}

\begin{abstract}
Abstrak
Hipertensi merupakan kondisi kronik dengan definisi peningkatan tekanan darah sistolik lebih dari $140 \mathrm{mmHg}$ dan/atau diastolik lebih dari $90 \mathrm{mmHg}$. Hipertensi merupakan masalah global, di mana kurang lebih menyerang 1,13 miliar orang di dunia. Setiap peningkatan IMT akan meningkatkan risiko hipertensi. Tujuan penelitian ini untuk mengetahui pengaruh IMT terhadap kejadian hipertensi dan klasifikasi tekanan darah pada penduduk usia produktif di Kota Medan. Penelitian ini menggunakan metode potong lintang dengan kuesioner, pengukuran tekanan darah, berat badan, dan tinggi badan. Responden yang berpartisipasi dalam penelitian sebanyak 352 sampel, merupakan pekerja yang datang ke tempat pemeriksaan kesehatan di tempat kerjanya. Uji Anova yang dilanjutkan dengan Post Hoc Bonferroni dilakukan dalam studi tersebut. Hasilnya, terdapat pengaruh IMT terhadap kejadian hipertensi ( $p$-value $<0,001)$, dan terdapat perbedaan IMT terutama pada kelompok tekanan darah optimal, dengan hipertensi derajat 1, dan derajat 2 ( $p$-value $<0,001)$. Kesimpulan penelitian ini adalah terdapat pengaruh IMT terhadap kejadian hipertensi dan terdapat perbedaan IMT yang signifikan antara kelompok dengan tekanan darah optimal, hipertensi derajat 1 , dan derajat 2 ( $p$-value $<0,001)$
\end{abstract}

Kata kunci: hipertensi, indeks massa tubuh

\section{The Effect of Body Mass Index on Blood Pressure Classification at Productive Age in Medan City}

\begin{abstract}
Hypertension is a chronic condition characterized by elevated blood pressure, with systolic pressure of more than $140 \mathrm{mmHg}$ and/or diastolic pressure of more than $90 \mathrm{mmHg}$. Hypertension is a global problem, which has affected 1.13 billion people worldwide. Increase of body mass index (BMI) is associated with hypertension incidence. The purpose of this study was to find out the effect of body mass index to hypertension incidence and blood pressure classification at productive age citizen in Medan. This study used a cross sectional type approach with questionnaire, blood pressure measurement, body weight, and body height measurement. A total of 352 respondents participated in this study, all were workers who came to the workplace clinic. Anova test analysis was used, followed by Post Hoc Bonferroni in this study. Results showed that there was an effect of BMI to hypertension incidence ( $p$-value $<0,001$ ), and a significant difference in BMI between respondents with hypertension grade 1 and grade 2 group (p-value< 0,001). The study concludes that BMI affect hypertension incidence and there is significant difference of BMI between group optimal blood pressure, grade 1 hypertension, and grade 2 hypertension ( $p$-value $<0,001$ ).
\end{abstract}

Keywords: body mass index, hypertension

\section{Pendahuluan}

Hipertensi merupakan kondisi kronik yang didefinisikan dengan peningkatan tekanan darah, di mana tekanan sistolik lebih dari $140 \mathrm{mmHg}$ dan/atau diastolik lebih dari $90 \mathrm{mmHg}$ di usia dewasa muda hingga lansia pada dua kali pengukuran dengan selang waktu lima menit dalam 
keadaan tenang. ${ }^{1,2}$ Penyakit ini merupakan masalah global yang sudah menyerang kurang lebih 1,13 miliar orang di dunia. Terdapat 1,5 juta kematian akibat hipertensi terjadi setiap tahunnya di Asia Tenggara. Penduduk Indonesia rata-rata $34,1 \%$ terdiagnosis hipertensi, yang tertinggi terdapat di Provinsi Kalimantan Selatan sebesar 44,1\% dan terendah di Provinsi Papua 22,2\%. . $^{3-5}$

Klasifikasi Hipertensi berdasarkan American Heart Association (AHA) dibagi menjadi normal di mana sistolik $<130 \mathrm{mmHg}$, diastolik $<85$ mmHg, Normal-tinggi (sistolik 130- $139 \mathrm{mmHg}$, diastolik 85- $89 \mathrm{mmHg}$ ), hipertensi derajat 1 (sistolik 140-159 mmHg, diastolik 90- $99 \mathrm{mmHg}$ ), dan hipertensi derajat 2 (sistolik $\geq 160 \mathrm{mmHg}$, diastolik $\geq 100 \mathrm{mmHg}$ ). ${ }^{6}$ Klasifikasi di Indonesia sedikit berbeda yaitu, optimal $(<120 /<80)$, normal (120-129/80-84), normal-tinggi (130-139/85-89), hipertensi derajat 1 (140-159/90-99), hipertensi derajat 2 (160-179/100-109), hipertensi derajat 3 $(\geq 180 / \geq 110)$, dan hipertensi sistolik terisolasi $(\geq 140 /<90) .^{7}$

Hipertensi, mayoritas tidak diketahui penyebabnya, atau dikenal juga dengan istilah hipertensi esensial memiliki berbagai faktor risiko yang dapat meningkatkan terjadinya hipertensi antara lain: usia, jenis kelamin, kebiasaan merokok, latihan fisik, riwayat keluarga, pola diet, dan indeks massa tubuh (IMT). ${ }^{8,9}$ Proses terjadinya hipertensi esensial juga tergantung dari masingmasing faktor risiko yang dimiliki setiap individu, salah satunya IMT yang tinggi akan menyebabkan produksi sitokin pro inflamasi, overaktivitas simpatis, resisten terhadap leptin, sel lemak memproduksi adipokin dan overaktivitas sistem renin- angitensin- aldosteron. ${ }^{10}$ Telah ada penelitian, peningkatan indeksi massa tubuh meningkatkan kejadian hipertensi, peningkatan 1 poin IMT dapat meningkatkan $8 \%$ kejadian hipertensi. ${ }^{11,12}$

IMT merupakan indeks sederhana dari berat badan dalam kilogram dibagi terhadap tinggi badan kuadrat dalam meter yang digunakan sebagai indikator dari lemak tubuh, dan sebagai penapisan dari kategori berat badan. ${ }^{13}$ IMT diklasifikasikan menurut WHO, underweight $<18.5 \mathrm{~kg} / \mathrm{m}^{2}$, normal $18,5-24,9 \mathrm{~kg} / \mathrm{m}^{2}$, overweight $25-29,9 \mathrm{~kg} / \mathrm{m}^{2}$ dan obesitas $\geq 30 \mathrm{~kg} / \mathrm{m} 2$, sedangkan untuk di Asia Pasifik pengelompokannya berbeda, menjadi underweight $<18,5 \mathrm{~kg} / \mathrm{m}^{2}$, normal $18,5-22,9$ $\mathrm{kg} / \mathrm{m}^{2}$, overweight $23-24,9 \mathrm{~kg} / \mathrm{m}^{2}$, dan obesitas $\geq 25 \mathrm{~kg} / \mathrm{m}^{2} .{ }^{14}$

Akumulasi lemak dapat meningkatkan risiko terjadinya hipertensi, jaringan lemak adiposa menghasilkan sitokin seperti tumor necrosis factor alpha (TNF a) dan interleukin 6 (IL-6) yang dapat menyebabkan resistensi insulin dan berpengaruh terhadap kardiometabolik, walaupun mekanisme pasti masih belum diketahui secara jelas. ${ }^{15}$

Kota Medan merupakan kota terbesar di Provinsi Sumatera yang 29,1\% dari populasinya memiliki hipertensi, sampai sejauh ini belum ada penelitian yang mempelajari mengenai pengaruh IMT dengan keadian hipertensi di kota Medan.

Tujuan dilakukannya penelitian ini yaitu untuk mencari tahu bagaimana pengaruh IMT terhadap kejadian hipertensi terutama pada usia produktif di kota Medan.

\section{Metodologi}

Penelitian ini berlangsung di beberapa pabrik dan kantor kota Medan pada periode 6-13 Agustus 2014 dengan desain potong lintang menggunakan kuesioner. Metode pengambilan sampel menggunakan metode non random consecutive sampling, di mana semua pekerja yang datang ke tempat pemeriksaan kesehatan di tempat kerjanya yang memenuhi kriteria inklusi akan diikutsertakan dalam studi ini. Adapun besar sampel minimal yang dibutuhkan 63 responden per kelompok, totalnya 378 responden untuk 6 kelompok sesuai klasifikasi tekanan darah. Kesalahan tipe satu 5\%, kesalahan tipe dua $10 \%$, dengan simpang baku kedua kelompok $1 \mathrm{~kg} / \mathrm{m}^{2}$, serta perbedaan $0,5 \mathrm{~kg} / \mathrm{m}^{2}$ pada variabel indeks massa tubuh yang dianggap bermakna. Kriteria inklusi untuk studi tersebut antara lain, usia produktif dengan rentang usia 18 hingga 60 tahun, sedangkan kriteria eksklusinya adalah responden yang menolak untuk ikut serta dalam penelitian, memiliki atau pernah didiagnosis dokter hipertensi sekunder, dan responden yang tidak mengikuti pengambilan data dengan cara yang ditentukan oleh peneliti. Instrumen pengambilan data menggunakan kuesioner yang berisi data anamnesis, pemeriksaan fisik, dan penunjang berisi variabel yang dibutuhkan selama penelitian. Variabel bebas yang dibutuhkan adalah indeks massa tubuh, dengan pengukuran berat badan dan tinggi badan menggunakan meteran dan timbangan yang sudah divalidasi, pengukuran sebanyak dua kali yang selanjutnya akan dihitung menggunakan rumus untuk mendapatkan IMT. Pengukuran tekanan darah sebanyak dua kali dalam posisi duduk dengan jeda 15 menit antar pengukuran menggunakan sfigmomanometer yang sudah tervalidasi. Hasil IMT memiliki satuan kilogram per meter kuadrat, sedangkan klasifikasi tekanan darah sesuai Perhimpunan Dokter Hipertensi Indonesia yang terdiri dari 6 kelompok: optimal, normal, normal-tinggi, hipertensi derajat 1 , hipertensi derajat 2, dan hipertensi derajat 3, sedangkan klasifikasi menurut AHA: normal, 
normal- tinggi, hipertensi derajat 1, dan hipertensi derajat 2. Penelitian ini dianalisis menggunakan uji statistik deskriptif dan analitik. Analisis deskriptif meliputi klasifikasi tekanan darah dalam proporsi, dan indeks massa tubuh dalam bentuk mean, median, standar deviasi, minimum dan maksimum. Uji analitik yang digunakan berupa uji Anova. Analisis yang digunakan untuk uji normalitas, menggunakan Kolmogorov Smirnov dan Shapiro Wilk. Uji dinyatakan bermakna antar dua kelompok apabila memiliki p-value $<0,05$, selanjutnya dilanjutkan dengan uji Post Hoc Bonferroni.

\section{Hasil}

Total responden yang terlibat dalam penelitian ini berjumlah 352 orang, 113 berjenis kelamin lakilaki, dan 239 perempuan dengan usia produktif rentang 20 hingga 56 tahun rata-rata 41,13 $(9,93)$ tahun. Responden terdiri dari berbagai pekerjaan, karyawan swasta terbanyak dengan jumlah 305 $(8,6 \%)$ responden, paling sedikit pegawai negeri 1 $(0,3 \%)$. Ras terbanyak adalah ras Jawa 138 $(39,2 \%)$ orang, paling sedikit Arab Indonesia, Banjar, Bali, Makassar Cirebon dan lainnya masing-masing $1(0,3 \%)$.

Tabel 1. Sebaran Data Demografis Responden Penelitian

\begin{tabular}{|c|c|c|c|}
\hline Parameter & $\begin{array}{c}\mathbf{N} \\
(\%)\end{array}$ & $\begin{array}{c}\text { Mean } \\
(\mathrm{SD})\end{array}$ & $\begin{array}{c}\text { Med } \\
(\text { Min - Max })\end{array}$ \\
\hline \multicolumn{4}{|l|}{ Jenis Kelamin } \\
\hline . Laki- laki & $113(32,1 \%)$ & & \\
\hline . $\quad$ Perempuan & $239(67,9 \%)$ & & \\
\hline Usia & & $41,13(9,93)$ & $44(20-56)$ \\
\hline Tekanan Darah Sistolik & & $127,7(18,74)$ & $125(90-180)$ \\
\hline Tekanan Darah Diastolik & & $86,45(10,44)$ & $90(60-115)$ \\
\hline Berat Badan & & $62,48(12,42)$ & $62(38-100)$ \\
\hline Tinggi Badan & & $158,23(8,41)$ & $158(132-190)$ \\
\hline Indeks Massa Tubuh & & $24,95(4,62)$ & $24,63(16,38-40,37)$ \\
\hline \multicolumn{4}{|l|}{ Riwayat Hipertensi pada Keluarga } \\
\hline $\mathrm{Ya}$ & $182(51,7 \%)$ & & \\
\hline Tidak & $170(48,3 \%)$ & & \\
\hline \multicolumn{4}{|l|}{ Riwayat Merokok } \\
\hline . Pernah atau Masih & $73(20,7 \%)$ & & \\
\hline · $\quad$ Tidak & $279(79,3 \%)$ & & \\
\hline \multicolumn{4}{|l|}{ Riwayat Konsumsi Alkohol } \\
\hline $\mathrm{Ya}$ & $30(8,5 \%)$ & & \\
\hline . $\quad$ Tidak & $322(91,5 \%)$ & & \\
\hline Lama Tidur & & $6,18(1,73)$ & $6(1-12)$ \\
\hline \multicolumn{4}{|l|}{ Klasifikasi Tekanan Darah } \\
\hline Optimal & $106(30,1 \%)$ & & \\
\hline Normal & $80(22,7 \%)$ & & \\
\hline - Normal- Tinggi & $46(13,1 \%)$ & & \\
\hline . $\quad$ HT derajat 1 & $89(25,3 \%)$ & & \\
\hline HT derajat 2 & $28(8 \%)$ & & \\
\hline HT derajat 3 & $3(0,9 \%)$ & & \\
\hline
\end{tabular}

Hasil rata-rata tekanan darah sistolik 127,7 $( \pm 18,74) \mathrm{mmHg}$, dan diastolik $86,45( \pm 10,44)$ $\mathrm{mmHg}$. Berat badan responden rata-rata 62,48 $( \pm 12,42) \mathrm{kg}$, tinggi badan $158,23( \pm 8,41) \mathrm{cm}$, IMT
$24,95 \quad( \pm 4,62) \mathrm{kg} / \mathrm{m}^{2}$. Sebanyak $182 \quad(51,7 \%)$ responden memiliki riwayat hipertensi dalam keluarga. Mayoritas, $279(79,3 \%)$ responden tidak memiliki riwayat merokok, $322(91,5 \%)$ tidak 
memiliki riwayat konsumsi alkohol. Lama tidur secara rata-rata $6,18( \pm 1,73)$ jam. Klasifikasi tekanan darah mulai dari yang terbanyak di kelompok optimal $106(30,1 \%)$, lalu Hipertensi derajat 1 sebanyak $89(25,5)$, normal $80(22,7 \%)$, normal-tinggi $46(13,1 \%)$, Hipertensi derajat 2 ada 28 orang $(8 \%)$, dan terakhir Hipertensi derajat 3 sebanyak 3 orang $(0,9)$. (Tabel 1, Gambar 1, 2, dan 3).

Analisis deskriptif dilakukan untuk membandingkan perbedaan indeks massa tubuh dengan klasifikasi hipertensi. Kelompok dengan Tekanan darah optimal IMT rata-rata 23,51 $(4,24)$ $\mathrm{kg} / \mathrm{m}^{2}$, kelompok normal 24,81 $(4,87) \mathrm{kg} / \mathrm{m}^{2}$, normal-tinggi $24,35(3,67) \mathrm{kg} / \mathrm{m}^{2}$, hipertensi derajat $126,58(4,56) \mathrm{kg} / \mathrm{m}^{2}$, hipertensi derajat 2 $26,97(4,97) \mathrm{kg} / \mathrm{m}^{2}$, dan hipertensi derajat 321,93 (2) $\mathrm{kg} / \mathrm{m}^{2}$. Uji normalitas data menggunakan

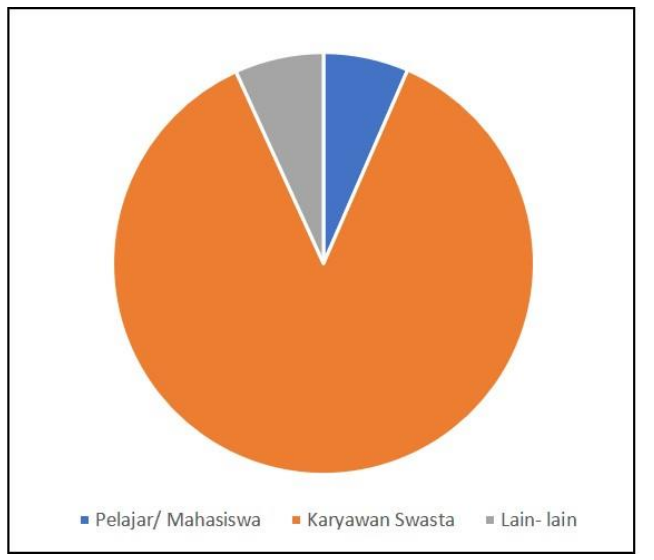

Gambar 1. Diagram Lingkaran Pekerjaan Responden
Shapiro Wilk untuk sampel yang kurang dari 50 dan Kolmogorov Smirnov untuk sampel yang lebih dari sama dengan 50. Hasilnya didapatkan sebaran data normal, sehingga menggunakan uji Anova satu arah. Hasil analisis menggunakan Anova satu arah, terdapat pengaruh IMT terhadap kelompok klasifikasi tekanan darah ( $p$-value $<0,001)$. (Tabel 2)

Setelah dilakukan uji analisis menggunakan Anova satu arah, uji Post Hoc Bonferroni dilakukan untuk melihat perbedaan setiap kelompoknya secara statistik. Hasilnya, terdapat perbedaan IMT yang bermakna antara kelompok yang klasifikasi tekanan darah optimal dengan hipertensi derajat 1 ( $p$-value $<0,001)$ dan juga dengan hipertensi derajat 2 (p-value< 0,001$)$. (Tabel 3 dan Grafik 1).

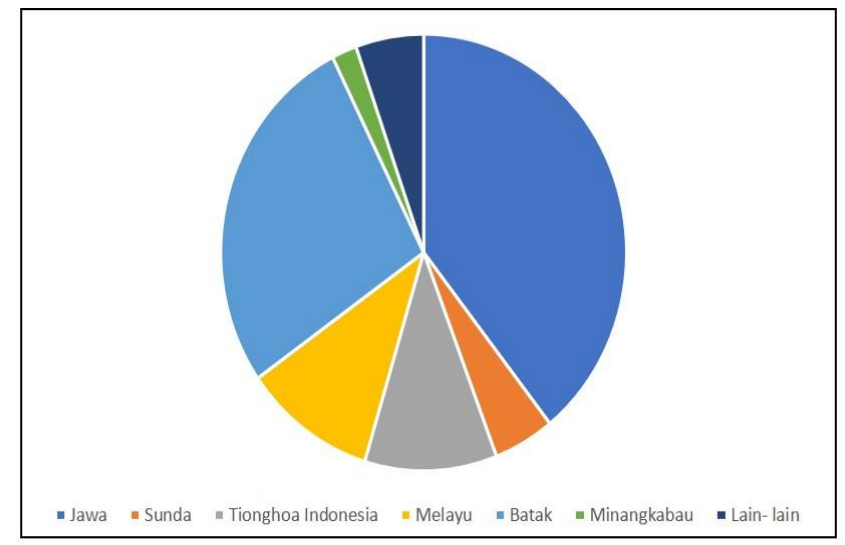

Gambar 2. Diagram Lingkaran Ras Responden

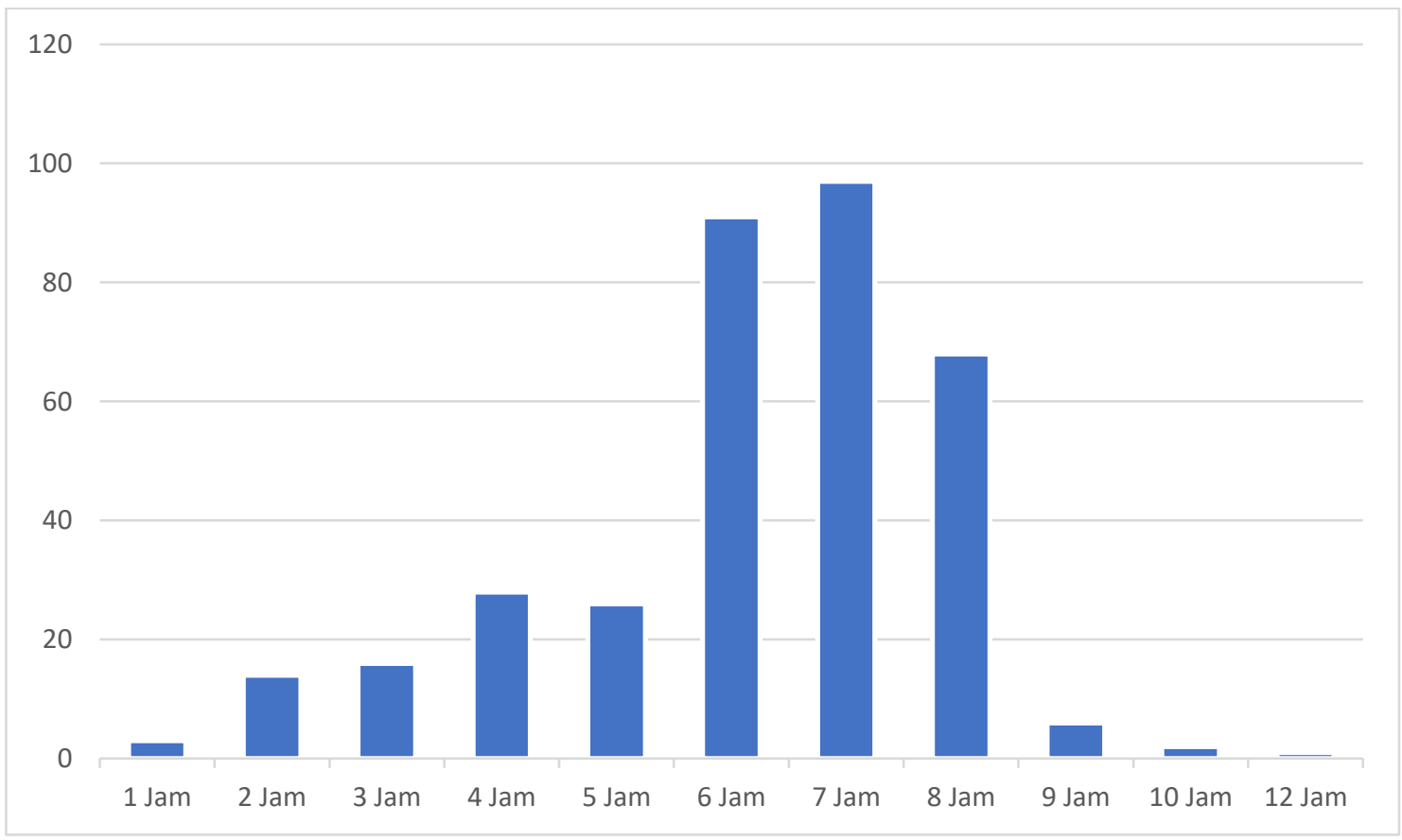

Gambar 3. Diagram Batang Lama Tidur Responden 
Tabel 3. Analisa Post Hoc Bonferroni terhadap Variabel IMT antar Kelompok Klasifikasi Tekanan Darah

\begin{tabular}{|c|c|c|c|c|c|c|}
\hline \multirow[t]{2}{*}{ (I) Grading } & \multirow[t]{2}{*}{ (J) Grading } & \multirow{2}{*}{$\begin{array}{c}\text { Mean } \\
\text { Difference (I- } \\
\text { J) }\end{array}$} & \multirow[t]{2}{*}{ Std. Error } & \multirow[t]{2}{*}{ Sig.** } & \multicolumn{2}{|c|}{ 95\% Confidence Interval } \\
\hline & & & & & Lower Bound & Upper Bound \\
\hline \multirow[t]{5}{*}{ Optimal } & Normal & $-1,3$ & 0,66 & 0,74 & $-3,25$ & 0,65 \\
\hline & Normal Tinggi & $-0,84$ & 0,78 & 1 & $-3,17$ & 1,48 \\
\hline & HT 1 & $-3,07 *$ & 0,64 & $<0,001^{*}$ & $-4,96$ & $-1,17$ \\
\hline & HT 2 & $-3,46^{*}$ & 0,94 & $<0,001^{*}$ & $-6,26$ & $-0,65$ \\
\hline & HT3 & 1,57 & 2,61 & 1 & $-6,14$ & 9,29 \\
\hline \multirow[t]{5}{*}{ Normal } & Optimal & 1,3 & 0,66 & 0,74 & $-0,65$ & 3,25 \\
\hline & Normal Tinggi & 0,45 & 0,82 & 1 & $-1,98$ & 2,89 \\
\hline & HT 1 & $-1,76$ & 0,68 & 0,15 & $-3,80$ & 0,26 \\
\hline & HT 2 & $-2,15$ & 0,97 & 0,42 & $-5,05$ & 0,73 \\
\hline & HT3 & 2,87 & 2,62 & 1 & $-4,88$ & 10,63 \\
\hline \multirow[t]{5}{*}{ Normal Tinggi } & Optimal & 0,844 & 0,78 & 1 & $-1,48$ & 3,17 \\
\hline & Normal & $-0,45$ & 0,82 & 1 & $-2,89$ & 1,98 \\
\hline & HT 1 & $-2,22$ & 0,81 & 0,09 & $-4,62$ & 0,16 \\
\hline & HT 2 & $-2,61$ & 1,06 & 0,22 & $-5,77$ & 0,54 \\
\hline & HT3 & 2,41 & 2,65 & 1 & $-5,44$ & 10,27 \\
\hline \multirow[t]{5}{*}{ HT 1} & Optimal & $3,07 *$ & 0,64 & $<0,001^{*}$ & 1,17 & 4,96 \\
\hline & Normal & 1,766 & 0,68 & 0,15 & $-0,26$ & 3,80 \\
\hline & Normal Tinggi & 2,22 & 0,81 & 0,09 & $-0,16$ & 4,62 \\
\hline & HT 2 & $-0,38$ & 0,96 & 1 & $-3,24$ & 2,46 \\
\hline & HT3 & 4,64 & 2,61 & 1 & $-3,09$ & 12,38 \\
\hline \multirow[t]{5}{*}{ HT 2} & Optimal & $3,46^{*}$ & 0,94 & $<0,001^{*}$ & 0,65 & 6,26 \\
\hline & Normal & 2,15 & 0,97 & 0,42 & $-0,73$ & 5,05 \\
\hline & Normal Tinggi & 2,61 & 1,06 & 0,22 & $-0,54$ & 5,77 \\
\hline & HT 1 & 0,38 & 0,96 & 1 & $-2,46$ & 3,24 \\
\hline & HT3 & 5,033 & 2,71 & 0,96 & $-2,97$ & 13,04 \\
\hline \multirow[t]{5}{*}{ HT3 } & Optimal & $-1,57$ & 2,61 & 1 & $-9,29$ & 6,14 \\
\hline & Normal & $-2,87$ & 2,62 & 1 & $-10,63$ & 4,88 \\
\hline & Normal Tinggi & $-2,41$ & 2,65 & 1 & $-10,27$ & 5,44 \\
\hline & HT 1 & $-4,64$ & 2,61 & 1 & $-12,38$ & 3,09 \\
\hline & HT 2 & $-5,03$ & 2,71 & 0,96 & $-13,04$ & 2,97 \\
\hline
\end{tabular}

* The mean difference is significant at the 0.05 level.

** Analisa uji statistik lanjutan menggunakan uji Post Hoc Bonferoni 


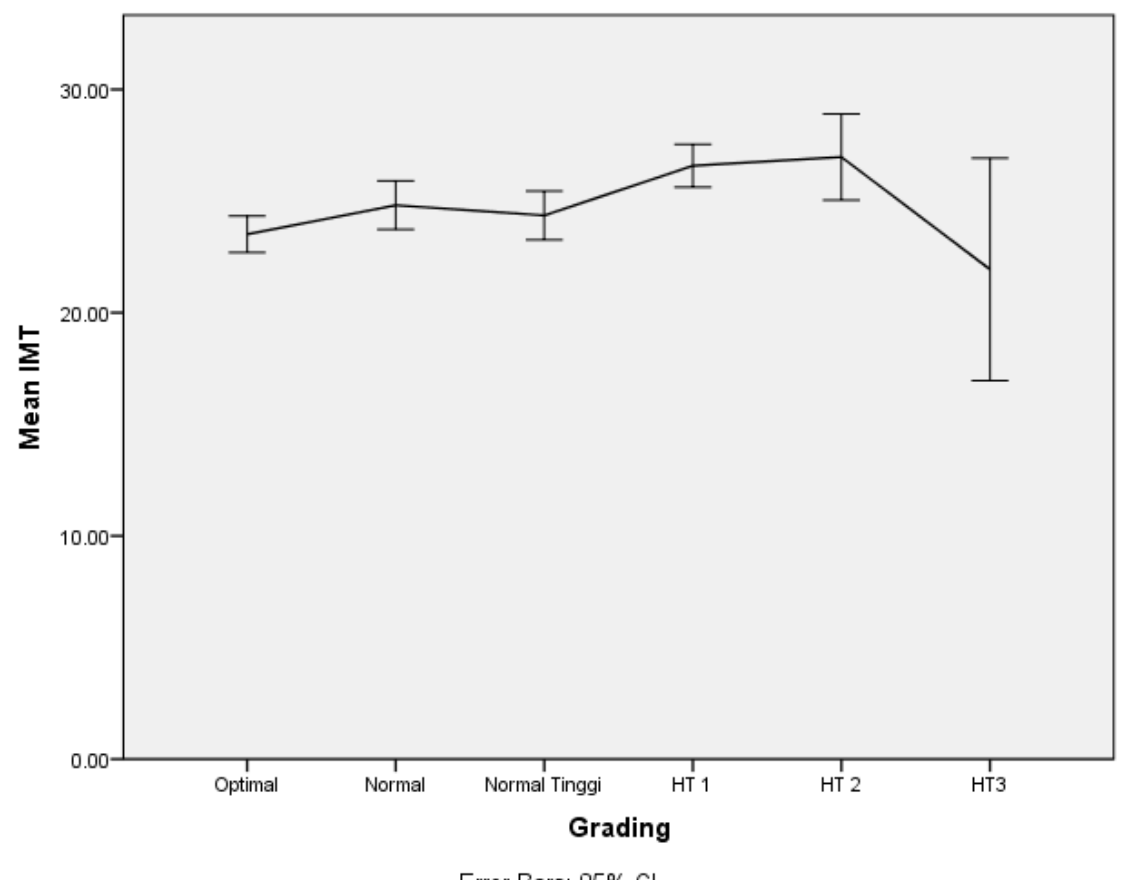

Gambar 4. Perbedaan IMT antar Kelompok Klasifikasi Tekanan Darah

\section{Pembahasan}

Pengaruh IMT terhadap tekanan darah telah banyak diteliti, penelitian sebelumnya yang berlokasi di Asia Selatan, mengatakan bahwa peningkatan IMT hingga batas overweight atau obesitas berbanding lurus terhadap peningkatan tekanan darah, termasuk semua kelompok etnis dan jenis kelamin laki- laki. Hal ini secara langsung membuktikan bahwa penurunan IMT berapapun maka akan menurunkan pula angka kejadian hipertensi dalam skala luas, menurunkan angka terapinya juga. ${ }^{16,17}$ Perbedaan IMT dengan setiap kelompok tekanan darah juga terlihat dalam penelitian kami di mana terdapat perbedaan hingga 3 poin IMT antara kelompok tekanan darah optimal dengan hipertensi derajat 1 atau 2.

Studi lainnya juga menyatakan bahwa IMT yang tinggi $\left(>28 \mathrm{~kg} / \mathrm{m}^{2}\right)$ lebih meningkatkan risiko terjadinya hipertensi ( $p$-value $<0,05)$ ditambah dengan faktor risiko lain seperti diabetes, hipertrigliseridemia, kebiasaan merokok, jenis kelamin perempuan. ${ }^{18}$ Indeks massa tubuh yang tinggi dalam studi kami juga mayoritas terdapat pada kelompok yang klasifikasi tekanan darahnya hipertensi, sehingga sesuai dengan penelitian yang telah dilakukan sebelumnya.

Tabel 2. Perbedaan IMT dengan klasifikasi Hipertensi

\begin{tabular}{|c|c|c|c|c|c|c|c|c|}
\hline \multirow{3}{*}{$\begin{array}{l}\text { Tekanan } \\
\text { Darah }\end{array}$} & \multicolumn{5}{|c|}{ Indeks Massa Tubuh $\left(\mathrm{kg} / \mathrm{m}^{2}\right)$} & \multirow{2}{*}{\multicolumn{2}{|c|}{$\begin{array}{c}\text { 95\% Confidence Interval for } \\
\text { Mean }\end{array}$}} & \multirow{3}{*}{$\boldsymbol{P}^{*}$} \\
\hline & \multirow{2}{*}{ Mean } & \multirow{2}{*}{ Min } & \multirow{2}{*}{ Max } & \multirow{2}{*}{ SD } & \multirow{2}{*}{ Std. Error } & & & \\
\hline & & & & & & Lower Bound & Upper Bound & \\
\hline Optimal & 23,51 & 16,46 & 33,41 & 4,24 & 0,41 & 22,69 & 24,32 & \multirow{6}{*}{$<0,001$} \\
\hline Normal & 24,81 & 16,38 & 40,37 & 4,87 & 0,54 & 23,72 & 25,90 & \\
\hline Normal Tinggi & 24,35 & 16,94 & 31,63 & 3,67 & 0,54 & 23,26 & 25,44 & \\
\hline HT 1 & 26,58 & 17,44 & 39,8 & 4,56 & 0,48 & 25,62 & 27,54 & \\
\hline HT 2 & 26,97 & 17,58 & 38,54 & 4,97 & 0,93 & 25,04 & 28,90 & \\
\hline HT 3 & 21,93 & 19,71 & 23,61 & 2,00 & 1,15 & 16,95 & 26,92 & \\
\hline
\end{tabular}

*Pengujian statistik menggunakan Anova One Way dikarenakan sebaran data menurut Kolmogorov-Smirnov dan Shapiro-Wilk menunjukan sebaran data yang normal 
Penelitian sebelumnya juga mempelajari mengenai peningkatan IMT yang berhubungan dengan kejadian hipertensi. Studi ini menyatakan bahwa pada pasien normotensif rata-rata peningkatan IMT sebesar $0,3 \mathrm{~kg} / \mathrm{m}^{2}$, sedangkan pada pasien hipertensi peningkatannya sebanyak $2,4 \mathrm{~kg} / \mathrm{m}^{2}$ setiap musim. Peningkatan IMT berarti terdapat penambahan lemak visceral, yang akan memicu berbagai hormon dan sitokin pro inflamasi lalu mengakibatkan resistensi insulin, peningkatan sistem renin- angiotensin-aldosteron, reabsorpsi natrium dan disfungsi endotelial dan akan berakhir pada peningkatan tekanan darah dan risiko kardiovaskular. Studi sebelumnya mempelajari mengenai penurunan IMT dan kejadian hipertensi, dari 490 orang obesitas melakukan intervensi gaya hidup sehingga menurunkan berat badannya, hasilnya tekanan darah sistolik menurun sebanyak $23 \mathrm{mmHg}$ dan diastolik $9 \mathrm{mmHg}$ ( $p$-value $=$ 0,005). ${ }^{19-21}$ Pada penelitian kami juga terdapat peningkatan rata- rata IMT seiring dengan peningkatan tekanan darah.

Tekanan darah pada orang dengan IMT tinggi dihubungkan dengan peningkatan curah jantung dan resistensi vaskular yang relatif normal. Orang normotensif dengan IMT tinggi, memiliki resistensi vaskular yang berbeda ditambah peningkatan sistem renin angiotensin aldosteron yang dapat lama kelamaan meningkatkan tekanan darah, baik laki-laki atau perempuan yang memiliki IMT lebih dari $30 \mathrm{~kg} / \mathrm{m}^{2}$ memiliki risiko 5 kali lebih besar untuk terserang hipertensi dibandingkan dengan individu dengan IMT kurang dari $20 \mathrm{~kg} / \mathrm{m}^{2}$. Peningkatan berat $4,5 \mathrm{~kg}$ dapat meningkatkan sistolik sebanyak $4 \mathrm{mmHg} .{ }^{22}$ Penelitian lain juga membandingkan risiko terjadinya hipertensi pada kelompok studi yang IMT rendah (underweight dan normal) dengan IMT tinggi (overweight dan obesitas), hasilnya semakin tinggi IMT, semakin berhubungan juga dengan kejadian hipertensi dan DM tipe 2, sedangkan pada kelompok lainnya, tidak terbukti adanya hubungan. ${ }^{23}$ Perbedaannya, hal tersebut tidak diteliti dalam penelitian ini.

Angka kejadian hipertensi 1,56 kali lebih besar pada usia di atas 50 tahun, dan 2 kali lebih besar pada usia di atas 70 tahun dikarenakan penebalan arteri seiring bertambahnya usia. ${ }^{24}$ Studi di Portugal menunjukkan bahwa kejadian hipertensi pada usia di bawah 40 tahun sebesar 40 (laki- laki), 23,1 (perempuan) per 1000 orang- tahun, dan meningkat menjadi 62 (laki- laki), 53,1 (perempuan) pada usia 40 hingga 60 tahun. ${ }^{25}$ Studi lainnya menyatakan juga, bahwa terdapat hubungan di mana durasi tidur yang pendek (kurang dari 7 jam) akan meningatkan kejadian hipertensi $(p$-value $<0,001)$. Hal tersebut juga tidak diteliti dalam penelitian ini.

Pendeknya durasi tidur dapat menjadi sumber stress mental, sehingga mengaktifkan sistem medulla simpatis dan sistem renin-angiotensinaldosterone, sehingga lama tidur yang kurang dari 7 jam sangat berdampak pada peningkatan risiko hipertensi, terutama yang durasi tidurnya kurang dari 4 jam (p-value $<0,0005)$, lama tidur 5 jam ( $p$ value $<0,0005) .{ }^{26,27}$

\section{Simpulan}

Simpulan penelitian ini adalah terdapat pengaruh IMT terhadap kejadian hipertensi pada usia produktif ( $p$-value $<0,001)$. Penelitian ini juga membuktikan, terdapat perbedaan signifikan antara kelompok yang tekanan darah optimal dengan hipertensi derajat 1 dan derajat 2 ( $p$-value< $0,001)$, di mana hipertensi derajat 3 tidak bisa menjadi acuan karena terbatasnya jumlah sampel.

\section{Ucapan terima Kasih}

Terima Kasih kepada wahana yang sudah memberikan izin, sarana dan fasilitas untuk dilaksanakannya penelitian ini, antara lain PT. Univista Utama, Deli Maya Sari Handicraft, PT. Voltama Vista Megah, dan PT. Sinar Cahaya Alam.

\section{Daftar Pustaka}

1. Ramzy I. Definition of hypertension and pressure goals during treatment (ESC-ESH Guidelines 2018) [Internet]. Vol. 17. [cited 2020 Aug 15]. Available from: https://www.escardio.org/Journals/E-Journalof-Cardiology-Practice/Volume-

17/definition-of-hypertension-and-pressuregoals-during-treatment-esc-esh-guidelin,

2. Infodatin. Hipertensi Si Pembunuh Senyap [Internet]. Jakarta: Kementrian Kesehatan Republik Indonesia; 2019 p. 1-10. Available from:

https://pusdatin.kemkes.go.id/resources/down load/pusdatin/infodatin/infodatin-hipertensisi-pembunuh-senyap.pdf

3. WHO. Hypertension [Internet]. World Health Organization. 2019 [cited 2020 Aug 15]. Available from: https://www.who.int/newsroom/fact-sheets/detail/hypertension

4. Oliva RV. A review on the status of hypertension in six Southeast Asian Countries. Hypertens J. 2019;5:4. 
5. KEMENKES. Hasil Utama RISKESDAS 2018. Jakarta: Kementrian Kesehatan Republik Indonesia

6. Unger T, Borghi C, Charchar F, Khan NA, Poulter NR, Prabhakaran D, et al. 2020 International Society of Hypertension Global Hypertension Practice Guidelines. Hypertension. 2020 Jun 1;75(6):1334-57.

7. Lukito AA, Harmeiwaty E. Konsensus Penatalaksaan Hipertensi 2019. Jakarta: Perhimpunan Dokter Hipertensi Indonesia; 2019.

8. Iqbal AM, Jamal SF. Essential hypertension. In: StatPearls [Internet]. Treasure Island (FL): StatPearls Publishing; 2020 [cited 2020 Aug 15]. Available from: http://www.ncbi.nlm.nih.gov/books/NBK539 $859 /$

9. Landi F, Calvani R, Picca A, Tosato M, Martone AM, Ortolani E, et al. Body mass index is strongly associated with hypertension: results from the longevity check-up 7+ study. Nutrients [Internet]. 2018 Dec 13 [cited 2020 Aug 15];10(12). Available from: https://www.ncbi.nlm.nih.gov/pmc/articles/P MC6316192/

10. Saxena T, Ali AO, Saxena M. Pathophysiology of essential hypertension: an update. Expert Rev Cardiovasc Ther. 2018 Dec 2;16(12):879-87.

11. Momin M, Fan F, Li J, Jia J, Zhang L, Zhang $\mathrm{Y}$, et al. Joint effects of body mass index and waist circumference on the incidence of hypertension in a community-based Chinese population. Obes Facts. 2020;2(2):245-55.

12. Fantin F, Giani A, Zoico E, Rossi AP, Mazzali $\mathrm{G}$, Zamboni M. Weight loss and hypertension in obese subjects. Nutrients [Internet]. 2019 Jul 21 [cited 2020 Aug 16];11(7). Available from:

https://www.ncbi.nlm.nih.gov/pmc/articles/P MC6682923/

13. CDC. Body Mass Index (BMI) [Internet]. Centers for Disease Control and Prevention. 2020 [cited 2020 Aug 15]. Available from: https://www.cdc.gov/healthyweight/assessing /bmi/index.html

14. Lim JU, Lee JH, Kim JS, Hwang YI, Kim TH, Lim SY, et al. Comparison of World Health Organization and Asia-Pacific body mass index classifications in COPD patients. Int $\mathbf{J}$ Chron Obstruct Pulmon Dis. 2017 Aug 21;12:2465-75.

15. Vaněčková I, Maletínská L, Behuliak M, Nagelová V, Zicha J, Kuneš J. Obesity-related hypertension: possible pathophysiological mechanisms. J Endocrinol. 2014;223(3):R6378.

16. Hossain FB, Adhikary G, Chowdhury AB, Shawon MSR. Association between body mass index (BMI) and hypertension in south Asian population: evidence from nationallyrepresentative surveys. Clin Hypertens. 2019;25(1):28.

17. Dua S, Bhuker M, Sharma P, Dhall M, Kapoor $\mathrm{S}$. Body mass index relates to blood pressure among adults. North Am J Med Sci. 2014;6(2):89-95.

18. Zhang Y, Hou LS, Tang WW, Xu F, Xu RH, Liu X, et al. High prevalence of obesity-related hypertension among adults aged 40 to 79 years in Southwest China. Sci Rep. 20191;9(1):15838.

19. Fletcher RD, Jones R, Moore H, Amdur R, Ahmed A, Kheirbek R, et al. Increased body mass index (bmi) promotes hypertension and worsens blood pressure control among US veterans. J Am Coll Cardiol. 2018 10;71(11 Supplement):A1817.

20. Seravalle G, Grassi G. Obesity and hypertension. Pharmacol Res. 2017;122:1-7.

21. Gilardini L, Redaelli G, Croci M, Conti A, Pasqualinotto L, Invitti C. Effect of a modest weight loss in normalizing blood pressure in obese subjects on antihypertensive drugs. Obes Facts. 2016;9(4):251-8.

22. Aronow WS. Association of obesity with hypertension. Ann Transl Med [Internet]. 2017 Sep [cited 2020 Aug 16];5(17). Available from:

https://www.ncbi.nlm.nih.gov/pmc/articles/P MC5599277/

23. Min D, Cho E. Associations among health behaviors, body mass index, hypertension, and diabetes mellitus: A path analysis. Medicine (Baltimore). 2018;97(22):e10981.

24. Shukuri A, Tewelde T, Shaweno T. Prevalence of old age hypertension and associated factors among older adults in rural Ethiopia. Integr Blood Press Control. 2019;12:23-31.

25. Lacruz ME, Kluttig A, Hartwig S, Löer M, Tiller D, Greiser KH, et al. Prevalence and incidence of hypertension in the general adult population: results of the CARLA-Cohort Study. Medicine (Baltimore). 2015;94(22):e952.

26. Feng X, Liu Q, Li Y, Zhao F, Chang H, Lyu J. Longitudinal study of the relationship between sleep duration and hypertension in Chinese adult residents (CHNS 2004-2011). Sleep Medicine. 2019;58:88-92.

27. Grandner M, Mullington JM., Hashmi SD, Redeker NS, Watson NF, Morgenthaler TI. 
Sleep duration and hypertension: analysis of > 700,000 adults by age and sex. Journal of Clinical Sleep Medicine. 2018 ;14(06):10319. 